\title{
Effect of Corporate Governance on Corporate Social Responsibility Disclosure: Empirical Evidence from Vietnamese Commercial Banks*
}

\author{
Quoc Thinh TRAN ${ }^{1}$, To Trang LAM ${ }^{2}$, Chi Danh LUU ${ }^{3}$
}

Received: August 01, 2020 Revised: September 28, 2020 Accepted: October 05, 2020

\begin{abstract}
Corporate social responsibility is an inevitable trend in the global context. It is the responsibility of the organizations to the community and society to ensure the fairness of the interests of stakeholders. This is an issue that deserves attention, not in the national or regional level, but as a global issue. The purpose of article is to examine the effect of corporate governance on corporate social responsibility disclosure of 155 samples of 31 Vietnamese commercial banks from 2015 to 2019 . The data of this study is employing time-series data and used the ordinary least squares to test the model. The results show that there are three factors that positively affect corporate social responsibility disclosure, namely, board size, foreign members of board, and audit committee. Thereby, the article proposes that board of director in Vietnamese commercial banks needs to raise awareness about corporate social responsibility, and the Central bank of Vietnam should monitor the disclosure of information regularly with severe sanctions on commercial banks that do not comply with the regulations of corporate social responsibility disclosure. This contributes to improving the information quality of the banking sector to meet the trend of international economic integration.
\end{abstract}

Keywords: Annual Report, Board Size, CSR Disclosure, Environment, Financial Information

JEL Classification Code: G34, M41, Q56

\section{Introduction}

The globalization landscape requires organizations to raise awareness of the corporate social responsibility (CSR). Branco and Rodrigues (2008) recognized that organizations must have a responsibility to their stakeholders such as employees, shareholders, investors, consumers, creditors

\footnotetext{
*Acknowledgements:

The authors would like to thank some experts of the Central bank of Vietnam and some leaders of Vietnamese commercial banks for their advice and support in this project.

${ }^{1}$ First Author and Corresponding Author. Associate Professor, Lecturer, Faculty of Accounting and Auditing, Industrial University of Ho Chi Minh City, Vietnam [Postal Address: 86 Nguyen Hong Street,

Ward 1, Go Vap District, Ho Chi Minh City, 70000, Vietnam]

Email: tranthinhktkt@gmail.com

${ }^{2}$ Lecturer, Faculty of Law, Ho Chi Minh City Open University, Vietnam. Email: trang.lamt@ou.edu.vn

${ }^{3}$ Lecturer, Faculty of Accounting and Auditing, Van Lang University, Vietnam. Email: tsluuchidanh@gmail.com

(c) Copyright: The Author(s)

This is an Open Access article distributed under the terms of the Creative Commons Attribution Non-Commercial License (https://creativecommons.org/licenses/by-nc/4.0/) which permits unrestricted non-commercial use, distribution, and reproduction in any medium, provided the original work is properly cited.
}

of public agencies, and non-governmental organizations. This is the responsibility that the public is expecting in the organization's actions on community and social issues. Akanfe et al. (2017) argued that companies reconcile social and environmental issues in their business operations in the face of social, legal and regulatory pressures and expectations of stakeholders. CSR is a very important issue in the competitive pressure. This is to help organizations solve the problem of economic benefits, but meet stakeholder expectations. CSR is an institutional move because of a number of legal constraints in addition to shareholder interests (Rehma et al., 2020).

In the banking sector, banks have an important role to play in the social and environmental performance of banks' lending policies to other industries. They perform essential functions in economics involved in the efficient allocation of capital. Therefore, the banking sector needs to promote to lead the economy (Kuzey \& Uyar, 2015). The banking industry recognizes that economic benefits must be considered from all aspects including social welfare and legal compliance (Ghabayen et al. 2016). Banks are encouraged to act more ethically and socially in their financing and investment activities to protect the legitimate interests of their stakeholders (Chiu, 2014). 
In recent times, Vietnam has made many amendments to regulations to contribute to increasing CSR, in particular a number of regulations have been enacted the Law on environmental protection (National Assembly of Vietnam, 2014). Particularly for corporate social responsibility disclosure (CSRD), Circular 155 provided an on disclosure of information related to CSR. Accordingly, Circular 155 required reporting on the environmental and social impacts of businesses (Vietnamese Ministry of Finance, 2015). The research on CSRD is limited in Vietnam, particularly in the banking sector, so this study chooses the subject of Vietnamese commercial banks. This is to have a clearer vision to contribute to improving CSRD for Vietnam in the context of international economic integration.

\section{Literature Review}

Corporate governance (CG) is the internal measures used to manage corporate activities. It is the relationship between the board of directors, and the shareholders of a company with related parties. Poudel (2015) said that CG is to form an operating mechanism to manage and operate activities to achieve those goals, as well as to monitor the company's performance. CG is a system through which businesses are directed and controlled for long-term results. Responsibility, transparency, fairness and publicity are the four pillars of CG. Hillman and Dalziel (2003) considered that CG is to monitor activities through the provision of financial resources to improve economic efficiency for business operations of enterprises. Qoyum (2017) checked that CG is the process of managing activities to help provide transparent information to users in order to bring the highest benefit to shareholders.

CSR is viewed on the basis of a number of different perspectives. Bowen (1953) recognized CSR as a corporate commitment on issues related to ethics. This ensures the reconciliation of the relationship between the economy, community and society. It is also fairness among the parties concerned. Carroll (1979) said that CSR is the commitment of the enterprise in the process of doing business. Such commitment is to ensure the harmonization of interests of CSR stakeholders. Poudel (2015) considered CSR to be responsive of organizations that must ensure legal, ethical, social and environmental in the process of doing business. This is the benefit of stakeholders to ensure fairness in the community. CSR is one of the business management strategies of companies in measuring economic growth and ethical values (Lee, 2018). CSRD is part of accountability in the CG context because CSRD can potentially have a potential impact on the well-being of shareholders (Zahari et al., 2020).

The relationship between CG and CSR is always a matter of concern and needs to be resolved harmoniously. CG often maintains operations to promote economic efficiency through profit maximization, while CSR is the opposite of profit maximization as it relates to the interests of external stakeholders. This may conflict with the interests of shareholders. CSR is part of the accountability in CG, as the disclosure of environmental issues can potentially have a potential impact on the well-being of shareholders (Poudel, 2015). CRSD has been shaped by reporting frameworks on CSR such as International Standards Organization (ISO), World Resources Institute (WRI) and Global Reporting Initiative (GRI) (Akanfe et al., 2017). However, this study will provide a new empirical basis on the basis of CSRD under Circular 155. CSR is measured across 14 key criteria, seven elements including management of raw materials; energy consumption; water consumption; compliance with the law on environmental protection; policies related to employees; report on responsibility for local community; green capital market activities under the guidance of the State securities committee (Vietnamese Ministry of Finance, 2015) (Appendix).

Previous studies have commonly used two fundamental theories such as legitimacy and stakeholder theory to consider the effect of CG on CSRD including Kuzey and Uyar (2015); Ghabayen et al. (2016); Orazalin (2019); and Jahid et al. (2020). The legitimate theory holds that the company must act in accordance with the value systems and social ethical norms (Dowling \& Pfeffer, 1975). According to this theory, a business associates with society with the community and the environment to ensure ethical values in the process of doing business. Enterprises implement CSRD to get social approval and community's expectations (Ghabayen et al., 2016). To ensure legitimacy, an organization also needs to uphold cultural plagiarism values according to the rules of society (Jahid et al., 2020). Furthermore, stakeholder theory explains the relationship between an organization and its stakeholders in terms of economic interests. This assures fairness between the parties (Freeman, 1984). Stakeholder theory explains contractual relationships between stakeholders including employees, suppliers, customers, and the public (Kuzey \& Uyar, 2015). Stakeholders are associated with each other in terms of interests so the company needs to pay attention to all related interests and it shows corporate responsibility (Orazalin, 2019).

Some previous studies have concerned the effect of CG on CSRD in the banking sector. Farook et al. (2011) studied 47 Islamic banks in 14 countries. The article uses ordinary least squares (OLS) to test. The results show that variables of CG have a positive impact on CSRD such as existence of board, number of board members, cross memberships, doctorate qualification of board member and reputable scholars on board. Jizi et al. (2014) reviewed United States listed banks for the period 2009-2011. OLS is uses to test the model. The results point that most of the variables of CG affect same direction to CSRD such as board size, board independence, CEO duality, board meetings and audit committee. However, there are several variables that have no effect on the CSRD including the audit committee size and financial expertise of audit committee. Kuzey and Uyar (2015) investigated twenty-six banks research. The sample of this research is collected between 2008 and 2012 in Turkey. The results explore that variables have a 
positive influence such as independent directors on board and female directors on board, while board size has no effect on CSRD.

Ghabayen et al. (2016) studied 147 Jordanian banking. The article uses a sample during a period from 2004 to 2013 and the multiple regression analysis is employed to examine. The results find that there are four variables affecting CSRD, of which board size has the same direction, while the other variables have the opposite effect including board independence, institutional directors and female directors. Qoyum et al. (2017) tested 10 Indonesian banks from 2011 to 2014. The article uses the panel regression is employed to test. The results demonstrate that supervision board has the same effect with CSRD, while the commissioner has the opposite effect with CSRD, but commissioner board has no effect on CSRD. Orazalin (2019) tested verified all Kazakhstan commercial banks listed for the period 2010-2016. The results indicate that only the percentage of female directors on the board has a positive impact on CSRD, while two variables have no effect on CSRD including board size and independent directors.

Matuszak et al. (2019) researched commercial banks, which operated during the years 2008-2015 in Poland. The article uses multivariate regression to test the model. The results elicit that the variables that have a positive influence on CSRD including members in the management board, female chief of management board, members in the supervisory board. While there are some variables that have no impact on CSRD such as female members in the management board, members in the supervisory board, foreign person in supervisory board. Hassan et al. (2020) studied a sample of 205 Malaysian companies. The study analyzes the multiple regression. The results find that the profession of board has an impact on CSRD.

Jahid et al. (2020) examined 30 publicly-listed banks in Bangladesh covering six years, from 2013 to 2018. The empirical analysis applies the OLS and the generalized method of moments. The results point that variables have a positive influence on CSRD such as board size, independent board member, female directors on the board, foreigners on the board. Meanwhile, some variables have the opposite influence with CSRD including accounting experts on the board, politicians on the board and audit committee size. Ridwan and Mayapada (2020) studied Islamic banks in Indonesia in the period 2011-2018. The article uses OLS to examine. The results show that the board of directors' meeting has a similar impact with CSRD, while the board of directors has the opposite effect of CSRD. Some variables have no impact on CSRS such as size of the audit committee, supervisory board, educational background of the supervisory board, reputable supervisory board.

Table 1: Description of independent variables

\begin{tabular}{|c|c|c|c|}
\hline $\begin{array}{l}\text { Variable } \\
\text { name }\end{array}$ & Description & Measurement & Previous studies related \\
\hline BSIZE & Board size & Number of board members & $\begin{array}{l}\text { Farook, Hassan \& Lanis (2011); Jizi et al. (2014); } \\
\text { Kuzey \& Uyar (2015); Ghabayen, Mohamad \& } \\
\text { Ahmad (2016); Matuszak, Rozanska \& Macuda } \\
\text { (2019); Orazalin (2019); Jahid et al. (2020). }\end{array}$ \\
\hline INDEP & $\begin{array}{l}\text { Independent } \\
\text { members of } \\
\text { Board }\end{array}$ & $\begin{array}{l}\text { Number of independent members } \\
\text { of board in the total number of } \\
\text { members of board }\end{array}$ & $\begin{array}{l}\text { Jizi et al. (2014); Kuzey \& Uyar (2015); } \\
\text { Ghabayen, Mohamad \& Ahmad (2016); Qoyum et } \\
\text { al. (2017); Orazalin (2019); Ridwan \& Mayapada } \\
\text { (2020); Jahid et al. (2020). }\end{array}$ \\
\hline DUAL & $\begin{array}{l}\text { Board } \\
\text { chairperson } \\
\text { duality }\end{array}$ & $\begin{array}{l}\text { Dummy variable, if there is } \\
\text { concurrently between board } \\
\text { chairman and CEO is } 1 \text { and the } \\
\text { opposite is } 0 .\end{array}$ & Jizi et al. (2014) \\
\hline FOREIGN & $\begin{array}{l}\text { Foreign members } \\
\text { of Board }\end{array}$ & $\begin{array}{l}\text { Number of foreign members in the } \\
\text { total number of board }\end{array}$ & $\begin{array}{l}\text { Matuszak,Rozanska \& Macuda (2019); Jahid et } \\
\text { al. (2020). }\end{array}$ \\
\hline MEETING & $\begin{array}{l}\text { Frequency of } \\
\text { meeting }\end{array}$ & $\begin{array}{l}\text { Number of board meetings in the } \\
\text { year }\end{array}$ & Jizi et al. (2014); Ridwan \& Mayapada (2020) \\
\hline FEMALE & $\begin{array}{l}\text { Female members } \\
\text { of Board }\end{array}$ & $\begin{array}{l}\text { Number of female members of } \\
\text { board in the total number of board }\end{array}$ & $\begin{array}{l}\text { Kuzey \& Uyar (2015); Ghabayen, Mohamad \& } \\
\text { Ahmad (2016); Matuszak,Rozanska \& Macuda } \\
\text { (2019); Jahid et al. (2020). }\end{array}$ \\
\hline AUDIT & Audit committee & $\begin{array}{l}\text { Dummy variable, if board is } \\
\text { consulted by Big4 auditing } \\
\text { company is } 1 \text { and the opposite is } 0 .\end{array}$ & $\begin{array}{l}\text { Jizi et al. (2014); Ridwan \& Mayapada (2020); } \\
\text { Jahid et al. (2020). }\end{array}$ \\
\hline
\end{tabular}




\section{Methodology}

The article uses quantitative methods by OLS through data panel time series (data panel) to test the regression model. The data of this study is collected from the website of State securities commission in Vietnam. Vietnam currently has 31 commercial banks, so data is collected with a sample including 155 observations from 31 Vietnamese commercial banks over the past five years from 2015 to 2019.

Based on a survey of experts of Central bank of Vietnam, combined with some independent variables of previous studies, the research model is designed as follows:

\section{DISCLOSURE $=\beta 0+\beta 1 *$ BSIZE $+\beta 2 *$ INDEP $+\beta 3 *$ DUAL $+\beta 4 *$ FOREIGN $+\beta 5^{*}$ MEETING + $\beta 6^{*}$ FEMALE $+\beta 7^{*}$ AUDIT $+\varepsilon$} banks

Dependent variable: CSRD of Vietnamese commercial

The article uses the CSRD recorded by weightless measurement method. CSRD of the commercial banks will be calculated as follows:

$$
I_{i j, t}=\frac{\sum_{i=1}^{n j} d_{i j}}{n_{j}}
$$

Where:

$I_{\mathrm{i}, \mathrm{t}}:$ Information disclosure index of commercial banks, $0 \leq \mathrm{I}_{\mathrm{j}} \leq 1$

$\mathrm{d}_{\mathrm{ij}}: 1$ if information item $\mathrm{i}$ is published; 0 if the information item $i$ is not published.

$n_{j}$ : number of information items on the notes if CSRD that commercial banks may publish.

t: figures for 2015-2019

\section{Research Findings}

According to the statistical results described in Table 2, the average rate of CSRD is $74.21 \%$, while the standard deviation is negligible. This shows that CSRD of Vietnamese commercial banks is quite high. This demonstrates that Vietnamese commercial banks comply strictly regulations related to CSRD. In general, descriptive statistical results of the independent variables accurately reflect the current status of the banking sector in Vietnam specifically as the average of the board size is 8.10 members, the independent members of board are $5.11 \%$, the average of board chairperson duality is $16.14 \%$, foreign members of board have the rate of $10.69 \%$, the average number of board meetings is 46.08 , the rate of female members of board is $5.38 \%$, and rate of board consulted by Big4 is $89.05 \%$. The independent variables have negligible standard deviations.

The results of correlation testing showed in Table 3 that these variables have a certain correlation. The relationship through the coefficients ranged from 0.2481 to 0.5476 . This relationship guarantees statistical significance.

According to the data in Table 4, the Adjusted R-squared is 0.7153 . It shows that the independent variable explains $71.53 \%$ of the variation of the dependent variable. The significance level of the probability (F-statistics) is 00000 (less than $5 \%$ ). The result has three variables that influence the same direction on CSRD including BSIZE and FOREIGN and AUDIT. Regression model is presented as follows:

$$
\begin{aligned}
\mathrm{CSRD} & =0.491+0.362 * \mathrm{BSIZE}+0.463 * \text { FOREIGN } \\
& +0.511 * \text { AUDIT }
\end{aligned}
$$

\section{Discussion and Policy Recommendations}

The study results show that there are three variables having the same influence with CSRD, including BSIZE, FOREIGN and AUDIT, of which AUDIT has the highest influence. The results of this study also reflect the current situation of the banking sector in Vietnam in recent years. This is also consistent with the experts of Central bank of Vietnam that these variables will significantly affect the CSRS of Vietnamese commercial banks.

Table 2: Descriptive Statistics

\begin{tabular}{|l|c|c|c|c|c|c|c|c|}
\hline Variables & CSRD & BSIZE & INDEP & DUAL & FOREIGN & MEETING & FEMALE & AUDIT \\
\hline Mean & 0.7421 & 8.1026 & 0.0511 & 0.1614 & 0.1102 & 46.0841 & 0.0538 & 0.8905 \\
\hline Maximum & 0.9251 & 18.0000 & 0.2692 & 0.2218 & 0.1800 & 183.0000 & 0.1601 & 1.0000 \\
\hline Minimum & 0.6124 & 5.0000 & 0.0000 & 0.0593 & 0.0000 & 8.0000 & 0.0000 & 0.0000 \\
\hline Std. Dev. & 0.0148 & 2.0146 & 0.0604 & 0.0127 & 0.0891 & 1.2164 & 0.0163 & 0.0128 \\
\hline Observations & 155 & 155 & 155 & 155 & 155 & 155 & 155 & 155 \\
\hline
\end{tabular}


Table 3: Correlations

\begin{tabular}{|l|c|c|c|c|c|c|c|c|}
\hline Variables & CSRD & BSIZE & INDEP & DUAL & FOREIGN & MEETING & FEMALE & AUDIT \\
\hline CSRD & 1.0000 & & & & & & & \\
\hline BSIZE & 0.5012 & 1.0000 & & & & & & \\
\hline INDEP & -0.2841 & -0.3021 & 1.0000 & & & & & \\
\hline DUAL & -0.3047 & -0.2908 & 0.4102 & 1.0000 & & & & \\
\hline FOREIGN & 0.5216 & 0.3841 & 0.3105 & 0.4108 & 1.0000 & & & \\
\hline MEETING & -0.3162 & 0.4012 & 0.2608 & 0.3017 & 0.4731 & 1.0000 & & \\
\hline FEMALE & 0.4013 & 0.3124 & 0.4027 & 0.2481 & 0.2541 & 0.4109 & 1.0000 & \\
\hline AUDIT & 0.5476 & 0.3147 & 0.4157 & 0.4068 & 0.3216 & 0.3148 & 0.4216 & 1.0000 \\
\hline
\end{tabular}

Source: Analytical data from Eviews 10

Table 4: Coefficients

\begin{tabular}{|l|c|c|}
\hline \multirow{2}{*}{ Variables } & \multicolumn{2}{|c|}{ CSRD } \\
\cline { 2 - 3 } & $\boldsymbol{\alpha}$ & P-value \\
\hline Constant & 0.491 & 0.0000 \\
\hline BSIZE & 0.362 & 0.0000 \\
\hline INDEP & -0.014 & 0.5041 \\
\hline DUAL & -0.106 & 0.3608 \\
\hline FOREIGN & 0.463 & 0.000 \\
\hline MEETING & -0.084 & 0.7128 \\
\hline FEMALE & 0.147 & 0.1405 \\
\hline AUDIT & 0.511 & 0.0000 \\
\hline Observations (N) & \multicolumn{2}{|c|}{155} \\
\hline R squared & \multicolumn{2}{|c|}{0.8064} \\
\hline R squared adjustment & \multicolumn{2}{|c|}{14.086} \\
\hline F-statistics & \multicolumn{2}{|c|}{0.0000} \\
\hline Probability. (F-statistics) & \multicolumn{2}{|c|}{} \\
\hline
\end{tabular}

This result is quite similar to some previous studies by Farook et al. (2011); Jizi et al. (2014); Ghabayen et al. (2016); Matuszak et al. (2019); Jahid et al. (2020) that BSIZE has a positive influence on CSRD. This explains that the more members of the board, the more appropriate views and opinions in the decision to disclose information. Moreover, FOREIGN has the same meaning with CSRD and this result is consistent with Jahid et al. (2020). The foreign members of the board are more likely to comply with the regulations, so when foreign members join the boards also promote CSRD. Besides, the role of Big 4 auditing firms has also contributed to increasing CSRD of commercial banks.

Vietnam is integrating the economy with the region and the world so it is necessary to comply CSRD. For the banking sector, this is the leading industry in the economy, so it is necessary to have pioneers in complying with regulations related to CSRD. This represents a responsibility to ensure fairness with stakeholders in the harmonious relationship between economic, community and social growth.

Accordingly, board of commercial banks should raise awareness of responsibility to the community and society. Board needs a long-term strategy to ensure more sustainable development than immediate benefits because CSR will create intangible value that increases the credibility and confidence of stakeholders. In addition, the Central bank of Vietnam should strengthen the regular monitor CSRD of Vietnamese commercial banks to improve the quality of information. In addition, the Central bank needs advocacy and consultation to raise board's awareness of CSR. The Central bank should also consider additional criteria related to CSRD in the credit rating of commercial banks. In addition, the Central of bank also regularly monitor for sanctions in the case commercial banks do not guarantee CSRD.

\section{Conclusion}

In the trend of economic globalization, CSR has always been interested in the banking sector in particular and businesses in general. The organizations must address the relationship between economic, community and social growth in order to ensure harmony among their stakeholders. According to the survey data of 155 samples of 31 Vietnamese commercial banks from 2015 to 2019, the results show that board size (BSIZE) and foreign members of board (FOREIGN) and audit committee (AUDIT) influence on CSRD. Therefore, in order to raise CSRD, Vietnamese commercial banks need to raise more awareness about CSR as well as the Central bank of Vietnam should strengthen the 
control CSRD of commercial banks and have strict sanctions in case commercial banks announce incomplete CSR. This contributes to improving the quality of information to meet the trend of international integration.

\section{References}

Akanfe, S. K., Michael, S. O. \& Bose, A. D. (2017). Determinant of Corporate Social Responsibility Disclosure in Nigeria. International Journal of Academic Research in Business and Social Sciences, 7, 565-580. DOI: 10.6007/IJARBSS/v7-i7/3122

Bowen, H. R. (1953). Social Responsibilities of the Businessman. New York, NY: Harper \& Brothers.

Branco, M. C. \& Rodrigues, L. L. (2008). Factors influencing social responsibility disclosure by Portuguese companies. Journal of Business Ethics, 83(1), 685-701.

Carroll, A. (1979). A three-dimensional conceptual model of corporate performance. The Academy of Management Review, 4(4), 497-505. http://dx.doi.org/10.2307/257850

Chiu, T. K. (2014). Putting responsible finance to work for Citi microfinance. Journal of Business Ethics, 119(2), 219-234.

Dowling, J., Pfeffer, J. (1975). Organizational legitimacy: societal values and organisational behaviour. Pacific Sociological Review, 18, 122-136. http:/ https://doi.org/10.2307/1388226

Farook, S., Hassan, K. \& Lanis, R. (2011). Determinants of corporate social responsibility disclosure: the case of Islamic banks. Journal of Islamic Accounting and Business Research, 2(2), 114-141. DOI: 10.1108/17590811111170539

Freeman, R. E. (1984). Strategic management: A stakeholder approach. Boston, MA: Pitman Publisher

Ghabayen, M. A., Mohamad, N. R. \& Ahmad, N. (2016). Board characteristics and corporate social responsibility disclosure in the Jordanian banks. Issues of the Journal, 12(1), 84-100. DOI:10.22495/cbv12i1c1art2

Hassan, L. S., Saleh, N. M. \& Ibrahim. I. (2020). Board diversity, company's financial performance and corporate social responsibility information disclosure in Malaysia. International Business Education Journal, 13(1), 23-49.

Hillman, A. J. \& Dalziel, T. (2003). Boards of Directors and Firm Performance: integrating Agency and Resource Dependence Perspectives. Academy of Management Review, 28(3), 383-396. https://www.jstor.org/stable/30040728

Jahid, A., Rashid, H. U., Hossain, S. Z., Haryono, S. \& Jatmiko, B. (2020). Impact of Corporate Governance Mechanisms on Corporate Social Responsibility Disclosure of Publicly-Listed Banks in Bangladesh. Journal of Asian Finance, Economics and Business, 7(6), 61-71. doi:10.13106/jafeb.2020.vol7.no6.061

Jizi, M., Salama, A., Dixon, R. \& Stratling, R. (2014). Corporate governance and corporate social responsibility disclosure : evidence from the US banking sector. Journal of Business Ethics, 125(4), 601-615. http://dx.doi.org/10.1007/s10551-013-1929-2
Kuzey, M. \& Uyar, C. K. A. (2015). The impact of ownership and board structure on corporate social responsibility (CSR) reporting in the Turkish banking industry. The International Journal of Business in Society, 15(3), 357-374. http://dx.doi. org/10.1108/CG-02-2014-0022

Lee, W. J. (2018). Group-affiliated Firms and Corporate Social Responsibility Activities. Journal of Asian Finance, Economics and Business, 5(4), 127-133. doi:10.13106/jafeb.2018.vol5. no4.127

Matuszak, L., Rozanska, E. \& Macuda, M. (2019). The impact of corporate governance characteristics on banks' corporate social responsibility disclosure: Evidence from Poland. Journal of Accounting in Emerging Economies, 9(1), 75-102. https://doi. org/10.1108/JAEE-04-2017-0040

National Assembly of Vietnam. (2014). Law on environmental protection. Vietnamese news. Retrieved May 30, 2020, from https://vanbanphapluat.co/law-no-55-2014-qh13-onenvironmental-protection

Orazalin, N. (2019). Corporate governance and corporate social responsibility (CSR) disclosure in an emerging economy: evidence from commercial banks of Kazakhstan. The International Journal of Business in Society, 19(3), 490-507. https://doi.org/10.1108/CG09-2018-0290

Poudel, R. L. (2015). Relationship Between Corporate Governance and Corporate Social Responsibility: Evidence From Nepalese Commercial Banks. The Journal of Nepalese Business Studies, IX(1), 137-144. https://doi.org/10.3126/jnbs.v9i1.14603

Qoyum, A., Mutmainah, L., Setyono, I. \& Qizam, J. (2017). The Impact of Good Corporate Governance, Company Size in Corporate Social Responsibility Disclosure: Case Study of Islamic Banking in Indonesia. Iqtshadva, 10(1), 130-159. http://dx.doi.org/10.21043/ iqtishadia.v10i1.2365

Rehma, Z. U., Zahid. M., Rahman, H. U., Asif, M., Alharthi , M., Irfan , M \& Glowacz , A. (2020). Do Corporate Social Responsibility Disclosures Improve Financial Performance? A Perspective of the Islamic Banking Industry in Pakistan. Sustainability, 12(3302), 1-18. http://doi:10.3390/su12083302

Ridwan, R. \& Mayapada, A. G. (2020). Does sharia governance influence corporate social responsibility disclosure in Indonesia Islamic banks? Journal of Sustainable Finance \& Investment, 3-20. DOI: $10.1080 / 20430795.2020 .1749819$

Vietnamese Ministry of Finance. (2015). Circular 155/2015-TTBTC on disclosure of information on the securities market. Vietnamese news. Retrieved May 30, 2020, from: https://vbpq.mof.gov.vn/Detail? contentType=Legal Document\&id=19070\&tab=99

Zahari, A. R., Esa, E., Rajadurai, J., Azizan. N. A. \& Tamyez, P. F. M. (2020). The Effect of Corporate Social Responsibility Practices on Brand Equity: An Examination of Malaysia's Top 100 Brands. Journal of Asian Finance, Economics and Business, 7(2), 271-280. doi:10.13106/jafeb.2020.vol7.no2.271 
Appendix: List of items on CSRD according to Circular 155

\begin{tabular}{|c|c|}
\hline No & Items on the environmental and social \\
\hline 1 & $\begin{array}{l}\text { 1. Management of raw materials: } \\
\text { 1.1. The total amount of raw materials used for the manufacture and packaging of the products as well as services of } \\
\text { the organization during the year. }\end{array}$ \\
\hline 2 & $\begin{array}{l}\text { 1. Management of raw materials: } \\
\text { 1.2. The percentage of materials recycled to produce products and services of the organization. }\end{array}$ \\
\hline 3 & $\begin{array}{l}\text { 2. Energy consumption: } \\
\text { 2.1. Energy consumption - directly and indirectly. }\end{array}$ \\
\hline 4 & $\begin{array}{l}\text { 2. Energy consumption: } \\
\text { 2.2. Energy savings through initiatives of efficiently using energy. }\end{array}$ \\
\hline 5 & $\begin{array}{l}\text { 2. Energy consumption: } \\
\text { 2.3. The report on energy saving initiatives (providing products and services to save energy or use renewable energy); } \\
\text { report on the results of these initiatives. }\end{array}$ \\
\hline 6 & $\begin{array}{l}\text { 3. Water consumption (water consumption of business activities in the year) } \\
\text { 3.1. Water supply and amount of water used. }\end{array}$ \\
\hline 7 & $\begin{array}{l}\text { 3. Water consumption (water consumption of business activities in the year) } \\
\text { 3.2. Percentage and total volume of water recycled and reused. }\end{array}$ \\
\hline 8 & $\begin{array}{l}\text { 4. Compliance with the law on environmental protection: } \\
\text { 4.1. Number of times the company is fined for failing to comply with laws and regulations on environment. }\end{array}$ \\
\hline 9 & $\begin{array}{l}\text { 4. Compliance with the law on environmental protection: } \\
\text { 4.2. The total amount to be fined for failing to comply with laws and regulations on the environment. }\end{array}$ \\
\hline 10 & $\begin{array}{l}\text { 5. Policies related to employees } \\
\text { 5.1. Number of employees, average wages of workers. }\end{array}$ \\
\hline 11 & $\begin{array}{l}\text { 5. Policies related to employees } \\
\text { 5.2. Labor policies to ensure health, safety and welfare of workers. }\end{array}$ \\
\hline 12 & $\begin{array}{l}\text { 5. Policies related to employees } \\
\text { 5.3. Training employees (The average number of training hours per year, according to the staff and classified staff; } \\
\text { The skills development and continuous learning program to support workers employment and career development). }\end{array}$ \\
\hline 13 & $\begin{array}{l}\text { 6. Report on responsibility for local community. } \\
\text { 6.1. The community investments and other community development activities, including financial assistance to } \\
\text { community service. }\end{array}$ \\
\hline 14 & 7. Green capital market activities under the guidance of the State securities committee. \\
\hline
\end{tabular}

